\title{
Women, High Technology, and Society Conference
}

\author{
Micaela di Leonardo
}

Yale University

In June, 1985, the Silicon Valley Research Group of the University of California, Santa Cruz, held a conference on Women, High Technology and Society. The Research Group conceived the topic broadly, to include not only the national and international effects of new technological (particularly microcomputer) developments on women in workplaces, but also the questions of women workers' responses and more general cultural effects of increasing societal computerization. The conference thus brought together researchers working in three general areas: women as production workers in computer and other firms heavily affected by high technology; women as white collar workers in increasingly computerized workplaces; and the cultural constructions of gender in social formations whose production base is increasingly computerized.

Researchers in the "production"' area focused on changing capital/labor relations as technologies changed and on issues of worker resistance or consent to new production relations. María Patricia Fernández-Kelly (University of California, San Diego), whose current group research project encompasses women garment and electronics workers in Los Angeles, Miami and New York City, reported an increase in self-contracting, home work and piecework in these industries. Aihwa Ong (University of California, Berkeley), who has done research among women microelectronics workers in Malaysia, discussed the differing "capitalist discourses" of American and Japanese transnationals operating there. While American managements impose capitalist work discipline through fostering the culture of female beauty, mobility and individualism, Japanese firms attempt to fit into prior sets of expectations through stressing women workers' joint moral obligations to parents and management.

Nance Goldstein (Thames Polytechnic) reported on her research on microelectronic firms in Scotland-the area of highest concentration of silicon chip production outside of California. Goldstein concentrated on gender differences in training programs for workers as the industry developed. She noted that men rather than women were recruited for training for new "skilled" 
jobs: employers both assumed that women were incapable of performing in these more complex occupations, and wished to retain a stable female production labor force.

While Fernandez-Kelly, Ong and Goldstein reported new means of control and consent enforcement, Devon Peña (Colorado College) found in his research on women electronics workers in Ciudad Juarez, Mexico, the development of genuinely oppositional structures among women maquila workers. Peña charted the evolution of a women's employee association from a management-approved discussion group to an organization which undertook its own research on deskilling and mounted effective worker protests.

One cluster of papers specifically considered racial and ethnic differences among women working in American high-technology firms. Patricia Zavella (University of California, Santa Cruz), in her review of research in the area, pointed out that there is as yet little research on this worker population, even though it is increasingly clear that minority women are particularly at risk as offices automate. Guadalupe Friaz (University of California, Berkeley), in her case study of a San Jose electronics firm, reported that minority women had higher turnover rates and lower job mobility than others. Carolyn Arnold reported similar findings in her study of four computer-related occupations. She suggested that these patterns may originate in race and gender segregation in training programs.

Moving away from the level of the firm, Judith Stacey (University of California, Davis) reported on her ongoing research on women and families in Silicon Valley. Stacey asserted that as a result of the changing political economy of the region, Silicon Valley displays an "exaggeration of national trends" toward female employment, high divorce rates, and high levels of femaleheaded families. Stacey's women informants revealed an "unlabelled" feminism and also an interest in unconventional religious expression.

Many popular commentators have assumed that the movement of computers into households heralds a new era of unalienated labor. Jamie Hurwitz (MIT), who has interviewed computer home workers and studied the ways in which this new working arrangement is popularly presented, pointed out that computer home work most often simply extends prior workplace patterns into households.

Finally, three conference papers focused primarily on cultural issues related to increased computerization and shifting gender relations. Lucy Suchman (Xerox Park) discussed the gendered origins of Artificial Intelligence theory in its implicit reliance on Western notions of rational intelligence, which are themselves gendered. Donna Haraway (University of California, Santa Cruz) considered the "sexual semiotics" of technology in modern life, commenting as well on the liberating nature of feminist science fiction. And Micaela di Leonardo discussed the two divergent discourses now current in considerations of new computer/human interactions. The "Second Self" vi- 
sion is broadly cultural and psychological, but considers neither gender divisions in computer use nor the fact that computers are technological items used primarily by waged workers. The "Labor's Bane" vision, on the other hand, tends to see the increasing computerization in the workplace solely in terms of job degradation, speedup and layoffs. di Leonardo argued for a unified vision that perceives computers both as technological elements of changing labor processes and as machines through which female and male workers culturally redefine themselves and their labor.

The revised conference papers, including an editorial introduction and additional commissioned work, have been entitled High Technology and Women's Work, and will be submitted to the University of California Press. 